\title{
Влияние термо-циклирования на прочность оксид-молибденовых композитов
}

\section{The effect of thermo-cycling on the strength of oxide-molybdenum composites}

\section{О. В. Петрова, И. А. Петухов}

Институт физики твердого тела РАН
O. V. Petrova, I. D. Petukhov

Osipyan Institute of Solid State Physics RAS

Поступила в редакцию 02.11.2021, принята к печати 19.11.2021

\section{Абстракт}

Исследовано влияние термоциклирования от 1100 до $1400^{\circ} \mathrm{C}$ на свойства композитов с оксидными волокнами различных со-

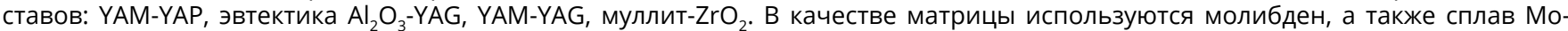
$\mathrm{Mo}_{5} \mathrm{SiB}_{2}-\mathrm{Mo}_{3} \mathrm{Si}$. Образцы получены методом внутренней кристаллизации. Показано, что влияние термоциклирования зависит от материала волокна. В частности, у образцов с волокнами YAM-YAP, муллит- $\mathrm{ZrO}_{2}$, эвтектика $\mathrm{Al}_{2} \mathrm{O}_{3}$-ҮAG величина прочности после термо-циклирования не снижается. Однако композиты с волокнами ҮAМ-ҮAG показали падение прочности после 50 циклов. Настоящая работа является первой в серии экспериментов с целью исследования влияния термоциклирования на свойства композитов с оксидными волокнами и металлической матрицей.

\section{Abstract}

The effect of thermo-cycling from 1100 to $1400^{\circ} \mathrm{C}$ on strength of composites with YAM-YAP, $\mathrm{Al}_{2} \mathrm{O}_{3}-\mathrm{YAG}_{\mathrm{A}}$ eutectic, YAM-YAG, mullite-ZrO oxide fibers was investigated. The matrix material was molybdenum, as well as $\mathrm{Mo}^{-} \mathrm{Mo}_{5} \mathrm{SiB}_{2}-\mathrm{Mo}_{3} \mathrm{Si}$ alloy. Composite specimens were obtained by the internal crystallization method. It is shown that the effect of thermo-cycling depends on a fiber material. In particular, for composites with YAM-YAP, mullite- $\mathrm{ZrO}_{2}, \mathrm{Al}_{2} \mathrm{O}_{3}-\mathrm{YAG}$ eutectic the strength after thermo-cycling did not decrease. However, composites with YAM-YAG fibers showed a decrease in strength after 50 cycles. This work is the first in a series of the experiments to study the effect of thermo-cycling on the properties of oxide/molybdenum composites.

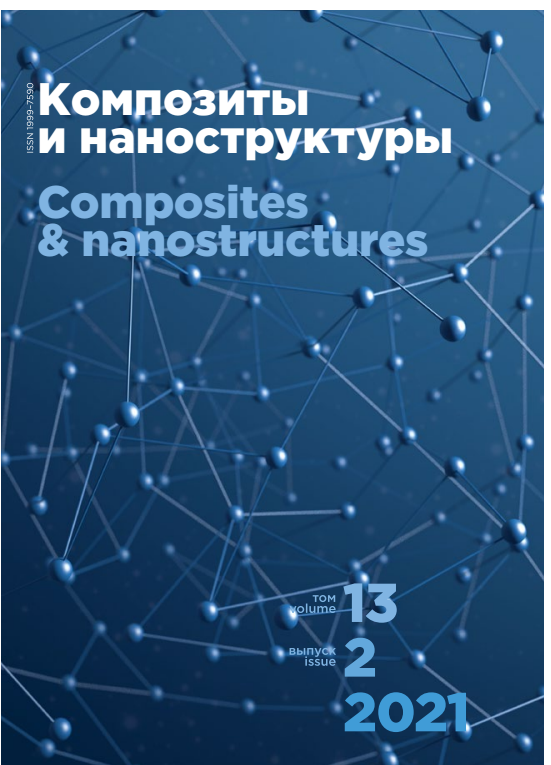

